\title{
PHYTOCHEMICAL SCREENING AND ANTIDIABETIC ACTIVITY OF DIFFERENT LEAF EXTRACTS FROM LOTUS (NELUMBO NUCIFERA GAERTN.) IN STREPTOZOTOCIN INDUCED MICE
}

\author{
RUTH MAYANA RUMANTI ${ }^{1 *}$, MARLINE NAINGGOLAN ${ }^{1}$, URIP HARAHAP ${ }^{2}$ \\ ${ }^{1}$ Department of Biological Pharmacy, Faculty of Pharmacy, University of Sumatera Utara, Medan, Indonesia. ${ }^{2}$ Department of Pharmacology, \\ Faculty of Pharmacy, University of Sumatera Utara, Medan, Indonesia. Email: ruth.mayana@yahoo.co.id
}

Received: 22 June 2017, Revised and Accepted: 28 August 2017

\section{ABSTRACT}

Objective: The present study is to evaluate the antidiabetic activity of various extract of Lotus (Nelumbo nucifera Gaertn.) leaf using hexane, ethyl acetate, and ethanol organic solvent.

Methods: Standard phytochemical screening method and streptozotocin induced diabetic mice.

Result: The phytochemical screening showed only ethyl acetate of lotus leaf extract contains the flavonoids. The ethyl acetate lotus leaf extract (dose level $150 \mathrm{mg} / \mathrm{kg}$ ) showed a significant reduction of the blood glucose.

Conclusion: The ethyl acetate extract of lotus leaf (N. nucifera Gaertn.) had the hypoglycemic effect on diabetic induced mice.

Keywords: Lotus, Diabetes mellitus, Antidiabetic, Streptozotocin, Mice.

(C) 2017 The Authors. Published by Innovare Academic Sciences Pvt Ltd. This is an open access article under the CC BY license (http://creativecommons. org/licenses/by/4. 0/) DOI: http://dx.doi.org/10.22159/ajpcr.2017.v10i12.20888

\section{INTRODUCTION}

Nowadays, there is a global increase in the prevalence of diabetes mellitus (DM), related to the lifestyles and the resulting surge from in obesity [1]. DM is the condition arising due to abnormal metabolism of carbohydrate, proteins, and fats. All of that happens by insulin deficiency or insulin resistance [2,3]. This disorder occurs worldwide and increasing quickly in all countries worldwide. According to the World Health Organization (WHO) projections, the prevalence of diabetes is likely to increase by $35 \%$. At present, there are over 171 million diabetics patient and this likely to increase to 366 million or more by the year 2030 [4]. Reasons for this rise are a sedentary lifestyle, obesity, consumption of high energy rich diet, higher life span, etc. [5]. The most majority of these cases will be Type 2 DM (non-insulin-dependent DM) [6].

In spite of the availability of various antidiabetic agents and its secondary complications continue to become a major problem in the world population. Medicinal plants and their bioactive compound are used as an alternative method to treat the diabetes patient throughout the world and popular as nutraceutical $[6,7]$. Literature reports more than 800 plants have been utilized as an empirical treatment for DM. One-tenth of them have been characterized as hypoglycemic plants with active compounds such as glycans, flavonoids, alkaloids, triterpenes, and mucilage gums [8].

Lotus (Nelumbo nucifera Gaertn) is an aquatic perennial plant from a family of Nelumbonaceae, which have several common names such as Indian lotus, Chinese water lily, and sacred lotus [6]. Lotus has been used as a food and medicine source for 1000 years $[9,10]$. Lotus produces a number of secondary metabolites such as alkaloids, flavonoids, steroids, triterpenoids, polyphenols, and glycosides. Due to its rich pharmaceutical value, lotus has been used to treat many diseases such as cancer, depression, diarrhea, antioxidant, and antibacterials [10-12]. Not just that, lotus leaf has been believed can treat the DM problem. In this regard, it makes great sense to evaluate the antidiabetic activity of various lotus leaf extract in streptozotocin (STZ)-induced diabetic mice model.

\section{METHODS}

Collection of plant material

Fresh lotus leaf was collected in the month of November 2016 from the local area of Padang Bulan and authenticated by Indonesian Institute of Sciences: Research Center for Biology. Voucher specimen was deposited in the Pharmacognosy Laboratory, Faculty of Pharmacy University of Sumatera Utara.

\section{Plant extraction preparation}

Extraction was done by a stratified maceration method that has been modified using organic solvent based on the multilevel polarity from low to high polarity solvent (hexane, ethyl acetate, and ethanol). $900 \mathrm{~g}$ of powdered lotus leaf are macerated in advance with the solvent hexane for 3 days, then filtered, do it continuously until the filtrate obtained is clear and colorless. The resulting dregs do the same thing for the solvent of ethyl acetate and ethanol [13].

Phytochemical screening of various lotus leaf extract Phytochemical screening carried out on various lotus leaf extract which are hexane, ethyl acetate, and ethanol includes examining the chemical secondary metabolites of alkaloids, flavonoids, glycosides, tannins, triterpenoids, and steroids [14-16].

Preparation of animals

Healthy adult male mice (20-35 g body weight) from animal house of Faculty of Pharmacy, University of Sumatera Utara were used for the study. Mice were housed in a polycarbonate cages in a room with 12 hrs day-night circle. They were fed on a standard pellet diet and water ad libitum. The study was approved by Animal Research Ethics Committees (AREC) of University of Sumatera Utara, and the experiments were conducted according to the ethical norms and AREC guidelines.

\section{Induction of diabetes}

Experimental diabetes was induced by single intraperitoneal injection of $55 \mathrm{mg} / \mathrm{kg}$ of STZ, freshly dissolved in citrate buffer ( $\mathrm{pH} \mathrm{4.5).} \mathrm{After}$ 
Table 1: Phytochemical screening result of various lotus leaf extract

\begin{tabular}{lll}
\hline Screening & $\begin{array}{l}\text { Hexane } \\
\text { extract }\end{array}$ & $\begin{array}{l}\text { Ethyl acetate } \\
\text { extract }\end{array}$ \\
\hline Alkaloids & Negative & Negative \\
Flavonoids & Negative & Positive \\
Glycosides & Negative & Negative \\
Tannins & Negative & Positive \\
Triterpenoid/steroids & Positive & Negative \\
\hline
\end{tabular}

Table 2: Effect of various extract of lotus leaf in blood glucose in STZ induction diabetic

\begin{tabular}{|c|c|c|c|c|c|}
\hline \multirow[t]{2}{*}{ Group } & \multicolumn{5}{|c|}{ Blood glucose levels (mg/dl) } \\
\hline & Day 3 & Day 6 & Day 9 & Day 12 & Day 15 \\
\hline Group I (normal) & $82.2 \pm 5.98$ & $82.5 \pm 4.51$ & $85.3 \pm 3.92$ & $83.5 \pm 5.45$ & $81.16 \pm 3.40$ \\
\hline Group II (diabetic mice) & $333.6 \pm 4.54^{* a}$ & $331.2 \pm 3.54^{* a}$ & $315.2 \pm 6.51^{* a}$ & $319 \pm 3.92^{* a}$ & $318.6 \pm 5.51^{* a}$ \\
\hline Group III (metformin 65mg/kg) & $197.4 \pm 4.40^{* b}$ & $137 \pm 2.90^{* b}$ & $116.8 \pm 4.74 * b$ & $98 \pm 2.28^{* \mathrm{~b}}$ & $78.4 \pm 3.25^{* \mathrm{~b}}$ \\
\hline Group IV (hexane extract $150 \mathrm{mg} / \mathrm{kg}$ ) & $380 \pm 4.43^{* b}$ & $371.4 \pm 5.80^{* b}$ & $403 \pm 4.17^{* b}$ & $393.6 \pm 3.95^{* b}$ & $384.8 \pm 2.99 * \mathrm{~b}$ \\
\hline Group V (ethyl acetate extract $150 \mathrm{mg} / \mathrm{kg}$ ) & $225.4 \pm 5.34^{* b}$ & $161.2 \pm 4.56^{* \mathrm{~b}}$ & $128.4 \pm 4.46^{* b}$ & $111.8 \pm 5.6^{* b}$ & $102.2 \pm 3.59 * \mathrm{~b}$ \\
\hline Group VI (ethanol extract $150 \mathrm{mg} / \mathrm{kg}$ ) & $281.4 \pm 5.34^{* b}$ & $241.4 \pm 4.11^{* b}$ & $223.8 \pm 5.44^{* b}$ & $192.8 \pm 3.87 * b$ & $169.4 \pm 4.04^{* b}$ \\
\hline
\end{tabular}

Values are given as mean \pm SEM for five mice in each group. ${ }^{* a} \mathrm{p}<0.001$ diabetic group was compared with normal group. ${ }^{* \mathrm{~b}} \mathrm{p}<0.001$ was compared with diabetic group.

SEM: Standard error mean, STZ: Streptozotocin

3 days of STZ injection, mice with fasting glucose above $200 \mathrm{mg} / \mathrm{dl}$ were considered as diabetic and included in the study.

\section{Experimental design}

The animals used for experimental design of antidiabetic test were divided into six groups of five animals for each group. Group 1 served as normal control animals given normal pellet and carboxymethyl cellulose $0.5 \%$ b/v. Group II served as diabetic mice and Group III mice were induced with STZ and treated with metformin $(65 \mathrm{mg} / \mathrm{kg})$ through oral way. Group IV mice were induced with STZ and treated with hexane lotus leaf extract ( $150 \mathrm{mg} / \mathrm{kg}$ ), Group V mice were induced with STZ and treated with ethyl acetate leaf extract $(150 \mathrm{mg} / \mathrm{kg})$, and Group VI mice were induced with STZ and treated with ethanolic leaf extract $(150 \mathrm{mg} / \mathrm{kg})$. The extract was given daily through oral way for 15 days.

\section{Statistical analysis}

All the data were expressed as mean \pm standard deviation. The significant difference of data between different groups was compared by ANOVA followed by Duncan's test.

\section{RESULTS}

\section{Phytochemical screening}

Screening results of various extract of lotus leaf extract showed different chemical compound in the different extract on Table 1.

\section{Effect of extracts on STZ induced diabetic mice}

The changes in levels of blood glucose of STZ induced diabetic mice are tabulated in Table 2. Fig. 1 show that the best result was in Group V which was using the $150 \mathrm{mg} / \mathrm{kg}$ of ethyl acetate extract of lotus leaf which showed a significant reduction in blood glucose levels $(\mathrm{p}<0.001)$.

\section{DISCUSSION}

DM is the most common multifactorial chronic disease and known as a very common metabolic disorder of human endocrine systems such as abnormal insulin production or metabolism and chronic hyperglycemia $[17,18]$. In the present study of antidiabetic activity of various lotus leaf extract (hexane, ethyl acetate, and ethanol) was evaluated by STZ induces diabetic mice. STZ has been widely used intravenously or intraperitoneally to induce the diabetic. The continuous treatment of lotus leaf extracts for 15 days produced a significant reduction in the blood glucose level in diabetic mice. The

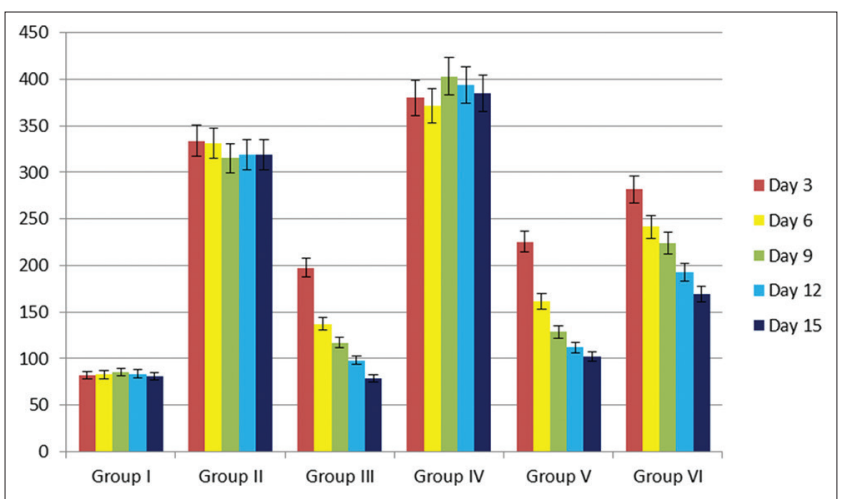

Fig. 1: Blood glucose level in mice (mg/dl)

best result was using $150 \mathrm{mg} / \mathrm{kg}$ of ethyl acetate lotus leaf extract. This result indicates that the ethyl acetate lotus leaf extract may be useful in the management of DM problem.

The effect of the ethanol lotus leaf extract can be good too, but the effect of ethyl acetate lotus leaf extract was better. This can happen because of the flavonoids compound which showed on phytochemical screening of ethyl acetate extract, while the other extracts did not have the flavonoids. The possible mechanism might be the potentiation of pancreatic secretion of insulin from existing $\beta$-cell [19]. Another possibility is because the flavonoids can protect the DNA from the oxidative damage, so it can resist the problem in $\beta$-cell [20].

\section{CONCLUSIONS}

The present study evaluated the antidiabetic activity of various lotus leaf extract using hexane, ethyl acetate and ethanol organic solvent in normal, and STZ induced diabetic mice. It has been prove that Lotus has the antidiabetic effect especially the $150 \mathrm{mg} / \mathrm{kg}$ of ethyl acetate extract. It could be used by diabetic patients to decrease the complication of diabetes. Therefore, further studies are necessary to determine the exact nature of active principles, the real mechanism of action and the safety of Lotus.

\section{ACKNOWLEDGMENTS}

The author wish to thank the Faculty of Pharmacy and Iksen, S.Farm., M.Si. for the support and providing the research work and publication. 


\section{REFERENCES}

1. King H, Aubert RE, Herman WH. Global burden of diabetes, 1995-2025: Prevalence, numerical estimates, and projections. Diabetes Care 1998;21(9):1414-31.

2. Zhang Y, Wu L, Ma Z, Cheng J, Liu J. Anti-diabetic, anti-oxidant and anti-hyperlipidemic activities of flavonoids from corn silk on STZ-induced diabetic mice. Molecules 2015;21:E7.

3. Parthasarathy R, Illavarasan R, Karrunakaran CM. Antidabetic activity of Thespesia populnea bark and leaf extrct against streptozotocin induced diabetic rats. Int J Pharmtech Res 2009;1(4):1069-72.

4. WHO. Definition and Diagnosis of Diabetes Mellitus and Intermediate Hyperglycemia. Geneva: WHO; 2006. p. 1-50.

5. Sikarwar MS, Patil MB, Kokate CK, Sharma S, Bhat V. Antidiabetic activity of Nerium indicum Leaf extractin alloxan-induced diabetic rats. J Young Pharm 2009;1(4):330-5.

6. Rumanti RM. Characterization of Simplicia and Chromatographic Analysis of Active Extract Lotus (Nelumbo nucifera Gaertn) which can Reduce Blood Glucose in mice. Thesis, Faculty of Pharmacy, University of Sumatera Utara No. 1-104; 2017.

7. Lal VK, Gupta PP, Awanish P. Hypoglycemic effect of Kyllinga trceps in STZ induced diabetic rats. J Diabetes Metab 2012;3(6):1-3.

8. Acosta-Patiño JL, Jiménez-Balderas E, Juárez-Oropeza MA, Díaz-Zagoya JC. Hypoglycemic action of Cucurbita ficifolia on Type 2 diabetic patients with moderately high blood glucose levels. J Ethnopharmacol 2001;77(1):99-101.

9. Moro CF, Yonekura M, Kouzuma Y, Agrawal GK, Rakwal R. Lotus-a source of food and medicine: Current status and future perspective in context of the seed proteomics. Int J Life Sci 2013;7(1):1-5.
10. Sheikh SA. Ethno-medicinal uses and pharmacological activities of lotus. J Med Plants Stud 2014;2(6):42-6.

11. Liu CM, Kao CL, Wu HM, Li WJ, Huang CT, Li HT, et al. Antioxidant and anticancer aporphine alkaloids from the leaves of Nelumbo nucifera Gaertn. cv. Rosa-plena. Molecules 2014;19(11):17829-38.

12. Xiaotian C, Changyin W, Jianxin C, Gbago O, Yuanda S. Antibacterial activity of lotus leaves (Nelumbo nucifera) against food-borne pathogens. Am J Biochem Biotechnol 2015;11(1):11-6.

13. Ditjen POM. Farmakope Indonesia. $4^{\text {th }}$ ed. Jakarta: Depkes RI; 1995. p. 896-8.

14. Depkes RI. Materia Medika. $6^{\text {th }}$ ed. Jakarta: Ditjen POM; 1995. p. 297-307.

15. Farnsworth NR. Biologycal and phytochemical screening of plants. J Pharm Sci 1996;55(3):225-76.

16. Harbone JB. Metode Fitokimia. Vol. 2. Bandung: ITB; 1987. p. 49.

17. Bharathi TR, Prakash HS. Comparative evaluation of antidiabetic and antioxidant potency of different extracts obtained from Memecylon species. Int J Pharm Pharm Sci 2017;9(2):187-91.

18. Priyanka P, Singh R. A systematic review on Indian floral biodiversity as eminent reserves for alternative treatment strategy of diabetes mellitus. Int J Pharm Pharm Sci 2016;8(4):10-9.

19. Kar MK, Swain TR, Mishra SK. Antidiabetic activity of Clerodendrum serratum moon leaves in streptozotocin-induced diabetic rats. Asian J Pharm Clin Res 2014;7(5):260-3.

20. Mujic A, Grdovic N, Mujic I, Mihailovic M, Zivkovic J, Poznanovic G, et al. Anti-oxidative effects of phenolic extracts from chestnut leaves, catkins and spiny burs in streptozotocin-treated rat pancreatic $\beta$-cells. Food Chem 2011;125:841-9. 